Jurnal Kejuruteraan 30(1) 2018: 23-29

https://doi.org/10.17576/jkukm-2018-30(1)

\title{
Pattern of Muscle Contraction in Car Pedal Control
}

\author{
(Corak Pengecutan Otot dalam Kawalan Pedal Kereta) \\ Nor Kamaliana Khamis ${ }^{\mathrm{a}, \mathrm{b},{ }^{*},}$, Baba Md Deros ${ }^{\mathrm{a}, \mathrm{c}}$, Mohd Zaki Nuawi ${ }^{\mathrm{a}, \mathrm{c}}$ \\ aProgramme for Mechanical Engineering, \\ ${ }^{b}$ Centre for Engineering Materials and Smart Manufacturing (MERCU), \\ ${ }^{c}$ Centre for Integrated Design of Advanced Mechanical System (PRISMA), \\ Faculty of Engineering \& Built Environment, Universiti Kebangsaan Malaysia, Bangi, Malaysia \\ Dieter Schramm \\ Faculty of Engineering, University of Duisburg-Essen, Duisburg, Germany
}

\begin{abstract}
Driver's discomfort has gained a lot of attention, especially among interested parties. There are many interacting factors involving both the driver and the interior components of the car that contribute to discomfort while driving. In this study, an investigation was carried out on the contraction of the lower leg muscle among drivers when operating the accelerator pedal. The main objective of this study was to determine the pattern of muscle contraction when operating the accelerator pedal with regard to three different actions; pressing, half-pressing and releasing. Eleven participants were involved in this investigation into the muscle pattern, whereby surface electromyography (SEMG) was used to measure the activity of the lower leg muscle, known as the tibialis anterior (TA). The data collection procedure on the selected muscle was in accordance with the SEMG recommendations for the Non-Invasive Assessment of Muscles. Based on the results, the TA depicted that the highest muscle contraction occurred during the releasing action. In addition, there were significant differences between each action in the T-test analysis with $p<0.05$. It can be concluded that the TA muscle works differently based on the car pedal actions.
\end{abstract}

Keywords: Driver; accelerator pedal; leg; tibialis anterior; electromyography

\section{ABSTRAK}

Ketidakselesaan pemandu telah menjadi tumpuan terutamanya di kalangan pihak yang berkepentingan. Terdapat pelbagai faktor yang menyumbang kepada ketidakselesaan ketika memandu, yang melibatkan kedua-dua nya iaitu pemandu dan komponen dalaman kereta. Dalam kajian ini, penyelidikan ke atas pengecutan otot bagi bahagian bawah kaki pemandu ketika mengendalikan pedal pemecut telah dilakukan. Objektif utama kajian ini ialah bagi menentukan corak pengecutan otot apabila mengendalikan pedal pemecut dalam tiga aksi berbeza; tekan, separa tekan dan lepas. Untuk memeriksa corak pengecutan otot ini, sebelas peserta telah dipilih untuk terlibat dalam eksperimen pemanduan bersimulasi dalam makmal. Penderia elektromyografi permukaan (SEMG) telah digunakan untuk mengukur aktiviti otot untuk bawah kaki, yang dikenali sebagai Tibialis Anterior (TA). Pengukuran SEMG dilakukan dengan menempatkan elektrod pada permukaan kulit dan aktiviti elektrik pada kanan TA di bawahnya direkodkan. Data mentah daripada penderia SEMG telah ditapis menggunakan tiga frekunesi berbeza, laluan tinggi, takuk dan laluan rendah. Kemudiannya, nilai Punca Min Kuasa Dua (RMS) akan dihasilkan berdasarkan peratusan Pengecutan Maksima Sukarela (\%MVIC). Prosedur pengumpulan data ke atas otot terpilih adalah berdasarkan cadangan Surface Electromyography for the Non-Invasive Assessment of Muscles (SENIAM). Hasil kajian ini menunjukkan bahawa TA mempamerkan pengecutan otot tertinggi ketika aksi melepaskan. Sebagai penutup, otot TA berkerja secara berbeza bergantung kepada aksi pedal kereta.

Kata kunci: Pemandu; pedal kereta; kaki; tibialis anterior; elektromyografi

\section{INTRODUCTION}

There are many factors that affect the driver when driving. The interaction between the driver and the interior components of the car, either for controlling the direction of the car and speed or adjusting the seat position, will influence the driver's condition. A study conducted by Fatollahzadeh (2006) showed that the car pedal location is highly correlated to the driver's preferable posture and the corresponding comfort. In fact, driving position is one of the factors leading to driver's fatigue and health risks. In addition, most of the health risk due to driving task concentrated on the upper extremities and at the lower back (Costanzo et al. 1999; Gyi et al. 1998; Hirao et al. 2006; Porter \& Gyi 1995). Hence, the driving position with regards to the driving task, should be given the utmost consideration in improving the car design and driver's condition. 
Many studies in the past literature focus on areas associated with assessment on driving task. Table 1 shows 14 studies with different objectives conducted in the past ten years from 2007 to 2017 on the interaction between the driver and the car. Based on Table 1, the car seat and steering wheel are two popular car components that frequently studied by the researcher. Only three studies were carried out on the car pedal. According to Table 1, these three studies related to the car pedal were focused on the road environment and vibration impact on the drivers.

TABLE 1. Investigation on car-driver interaction

\begin{tabular}{|c|c|c|c|c|c|}
\hline \multirow{2}{*}{ No } & \multirow{2}{*}{ Reference } & \multicolumn{4}{|c|}{ Main components } \\
\hline & & Seat & Steering & Gear & Pedal \\
\hline 1 & Adler (2007) & $\mathrm{x}$ & & & \\
\hline 2 & Bougard et al. (2008) & $\mathrm{x}$ & & & \\
\hline 3 & Kyung (2008) & $\mathrm{x}$ & & & \\
\hline 4 & De Waard et al. (2010) & & $\mathrm{x}$ & & \\
\hline 5 & Fouladi et al. (2011) & $\mathrm{x}$ & & & \\
\hline 6 & Döring et al. (2011) & & $\mathrm{x}$ & & \\
\hline 7 & Vilimek et al. (2011) & & & $\mathrm{x}$ & \\
\hline 8 & Auberlet et al. (2012) & & $\mathrm{x}$ & & $\mathrm{x}$ \\
\hline 9 & Kamp (2012) & $\mathrm{x}$ & & & \\
\hline 10 & Yusoff et al. (2012) & & & & $\mathrm{x}$ \\
\hline 11 & Maël et al. (2013) & $\mathrm{x}$ & & & \\
\hline 12 & Rudin-Brown et al. (2014) & & $\mathrm{x}$ & $\mathrm{x}$ & $\mathrm{x}$ \\
\hline 13 & Mossey et al. (2014) & & $\mathrm{x}$ & & \\
\hline 14 & Mansfield et al. (2017) & $\mathrm{x}$ & & & \\
\hline
\end{tabular}

Car pedals can be categorized into two or three functions, based on the type of transmission. The automatic transmission has only two pedals which are the accelerator and the brake, while there is an additional pedal to the manual transmission which is known as the clutch. Even though there are two different transmissions, the car pedal is one of the main components to control the car mainly in speeding and braking task (Wang et al. 2004). Throughout the journey, drivers are required to interact with the car pedals frequently due to unexpected traffic and road conditions as well as the environment. According to Tanaka et al. (2009), there are two types of contact conditions in pedaling, between the foot-sole and pedal-pad. The effects when the foot touches the heel of the foot pedal and the floor of the car will cause discomfort to the driver while driving.

In term of biomechanics, there are two leg positions referring to ankle joint movement; plantar flexion and dorsiflexion (Keene 2010). The plantar flexion is referred to the pressing of the pedal, while dorsiflexion is referred to the releasing of the pedal. Dorsiflexion happens when the driver releases the pedal with the ankle joint angle is less than $90^{\circ}$ and at the maximum of $70^{\circ}$. Meanwhile, the plantar flexion occurs when the driver presses the pedal with the ankle joint angle greater than $90^{\circ}$ and at the maximum of $140^{\circ}$.

This paper aims to investigate the effect of different actions when operating the accelerator pedal. Surface electromyography (SEMG) was used to measure the Tibialis Anterior (TA) muscle activity based on different pedal actions.
Basically, this paper contributes to the literature on the impact of muscle activity in two ways. First, this paper document an important relationship between pedal action and muscle activity value. Second, driver's position influence the driver's condition when operating the car pedal.

\section{METHODOLOGY}

PARTICIPANTS

Eleven participants (mean age of 29 years, mean height $=161$ $\mathrm{cm}$, mean weight $=56 \mathrm{~kg}$ ) were assigned from the population of staff and students at Universiti Kebangsaan Malaysia (UKM) to take part in this study. Each participant was required to attend one session, either in the morning session (from 9 am to $12 \mathrm{pm}$ ) or in the evening session (from $2 \mathrm{pm}$ to $5 \mathrm{pm}$ ). The inclusion criteria were all respondents held a full Malaysia driving license, had at least 3 years of driving experiences and aged between 22 to 35 years. The constriction of the age range was proposed to reduce variations in the results due to age, since even in normal ageing, people present slight perceptive variations that have a direct attitude towards driving (Antonson et al. 2014).

All participants were allowed to adapt with the car simulator setup and car seat adjustment before starting the experiment. The experiment was started after five minutes the participant had been in the driving position to allow them to adapt with the seat environment and fabrics. All participants understood and complied with the oral and written instructions provided by researcher for this experiment. Information about the experiment procedure was included. After receiving the complete information on the study, each participant signed an informed consent.

\section{EXPERIMENT DESIGN AND PROCEDURE}

The participant should sit on the car seat with the closest seated position to the car controls. The back rest of the car seat was fixed at $100^{\circ}$ in this study, as depicted in Figure 1. During recording the SEMG data, the participant must place their hand at 10 and 2 o'clock as shown in Figure 1. In addition, the participant need to ensure the right leg at the car pedal, while the left leg at the car simulator floor, near to clutch pedal.

\section{EXPERIMENT EQUIPMENT}

SEMG measurement was used in this study to investigate the muscle activity according to the different actions while operating the car pedal. A Trigno ${ }^{\mathrm{TM}}$ Personal Monitor with Parallel-Bar Sensors from Delsys Incorporation was used to collect these analog data of muscle activity with sample rate up to $1000 \mathrm{~Hz}$ interfaced with 5-channel signal amplifier. Figure 2 illustrates the Trigno ${ }^{\mathrm{TM}}$ Personal Monitor with Parallel-Bar Sensors. 


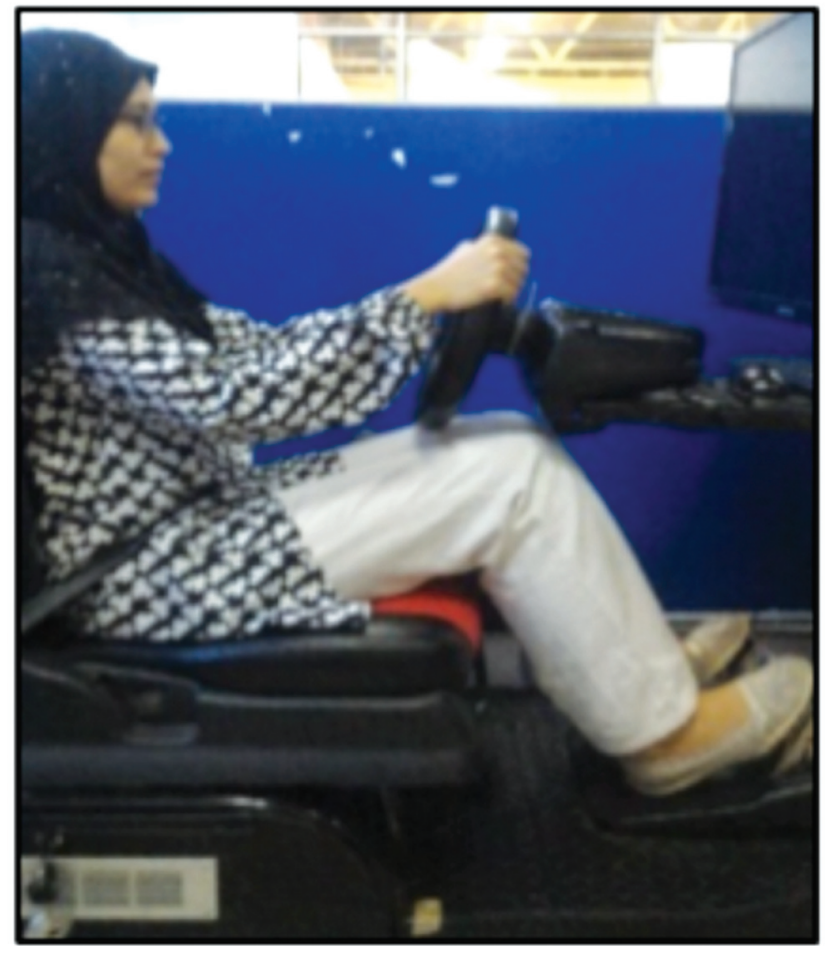

FIGURE 1. Participant's posture

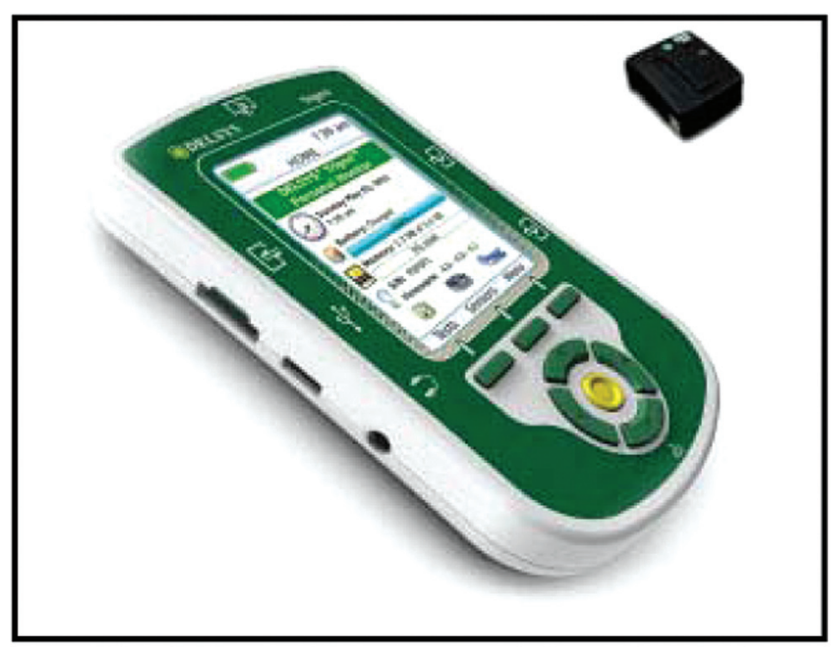

FIGURE 2. A Trigno ${ }^{\mathrm{TM}}$ Personal Monitor
The surface myo-electrical signal was converted to the analog data which later converted to digital data at the signal analysis personal computer interface. SEMG measurement was performed by placing electrodes on the skin's surface and electrical activity of the right TA underneath was recorded. The data collection procedure on the selected muscle was according to the Surface Electromyography for the NonInvasive Assessment of Muscles (SENIAM) recommendations. This section provides details on SEMG measurement used in this study.

\section{SEMG DATA COLLECTION PREPARATION}

Skin inspection were performed prior to the electrodes placement which to reduce the skin impedance and avoid noises on the SEMG readings. Proper skin preparation was required to improve the electrode-skin contact. All subjects shaved at the selected muscle belly, cleaning with alcohol, rubbing with gel and abrasion with an abrasive cream such as NuPrep (Florimond 2009). The SEMG electrodes were pasted directly on the selected muscles belly after careful palpation and parallel to its muscle fibers. The procedure of electrodes placement such as body posture, location of electrodes, orientation, clinical test and task for selected muscle are depicted in Table 2. The cross symbol in the figures inside the Table 2 indicates the selected muscle. After the electrodes were placed and fixed, the electrodes could be connected to the SEMG equipment and a clinical test could be performed to test whether the electrodes have been placed properly on the muscle and connected to the equipment so that a reliable SEMG signal can be recorded.

In this study, three main actions of the accelerator pedal (half press $=\mathrm{HP}$, release $=\mathrm{R}$ and full press $=\mathrm{FP}$ ) were recorded as shown in Figure 3. Roughly, five seconds is taken for each pedal action. This study is conducted to investigate the reaction of the leg muscle while performing the HP, R and FP.

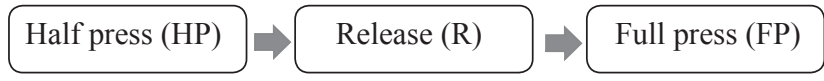

FIGURE 3. Main actions in accelerator pedal

TABLE 2. Identification of selected muscle and electrode placement position

\begin{tabular}{ccll}
\hline Muscle & Starting posture & Electrode placement & Clinical test \\
\hline TA $\quad$ Supine or sitting & $\begin{array}{l}\text { The electrodes need to be placed } \\
\text { at } 1 / 3 \text { on the line between the tip } \\
\text { of the fibula and the tip of the } \\
\text { medial malleolus }\end{array}$ & $\begin{array}{l}\text { Support the leg just above the ankle } \\
\text { joint with the ankle joint in } \\
\text { dorsiflexion and the foot in } \\
\text { inversion without extension of the } \\
\text { great toe. Apply pressure against } \\
\text { the medial side, dorsal surface of } \\
\text { the foot in the direction of plantar } \\
\text { flexion of the ankle joint and } \\
\text { eversion of the foot. }\end{array}$
\end{tabular}


SEMG DATA ANALYSIS

Figure 4 shows the flow chart of SEMG data analysis. In this study, the signal processing of the SEMG data was not conducted by using Delsys software. However, Matlab and Microsoft Excel software are two main operators in processing and analysing EMG data in this study. Before starting the experiment, the signal from the selected muscle should be tested to determine whether the muscle is working properly according to the driving activity. The muscle signal is displayed in the Delsys EMG works Acquisition software. If the muscle works as predicted, then, the experiment can be started. All raw data from the Delsys software are in the form ASCII file. These file need to be transferred to the Matlab software for further analysis as shown in Figure 4. All raw data need to be filtered by using three different frequencies, high pass, notch and low pass. Then, Root Mean Square (RMS) value will be produced based on percentage of Maximal Voluntary Contraction (\%MVIC). All data should be epoched before comparison based on the \%MVIC can be made.

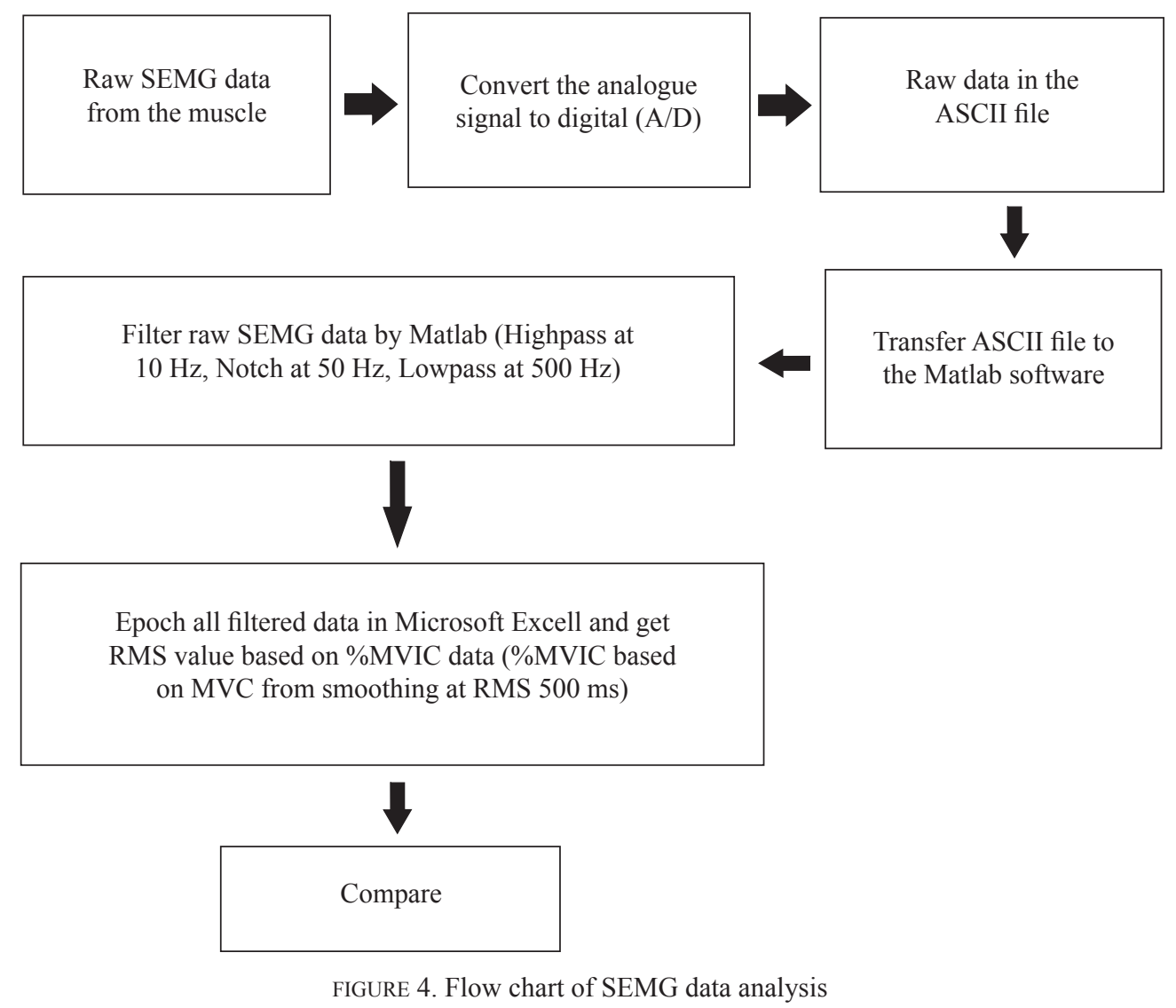

In short, there are two types of analysis were performed in this study, Temporal and Amplitude Analysis. Temporal Analysis was conducted to investigate the pattern of the muscle activity based on the pedal actions. Meanwhile, the Amplitude Analysis was carried out to determine muscle activity according to driving condition, either in contraction form or rest form. The value of muscle activity is in RMS. If the RMS of muscle activity below than 5 microvolt $(\mu \mathrm{V})$, it means the muscle is in the rest form (Florimond 2009). Basically, the Amplitude Analysis was performed at time domain and the amplitude unit is in $\mu \mathrm{V}$. Amplitude analysis was conducted at the stipulated epoch. The RMS equation in discrete time is defined in Equation (1), where $\mathrm{N}$ is the number of data and $n$ is the SEMG data.

$$
\begin{gathered}
\text { R.M.S }=\sqrt{\frac{1}{N}} \sum_{n=1}^{n} E M G[n]^{2} \\
\text { RESULTS AND DISCUSSION } \\
\text { TEMPORAL ANALYSIS }
\end{gathered}
$$

Figure 5 shows the example of Temporal Analysis for the TA. According to Figure 5, it is obvious that the TA is highly activated in releasing pedal position. Detailed analysis on this finding is performed using statistical analysis to determine the association between each parameter. 


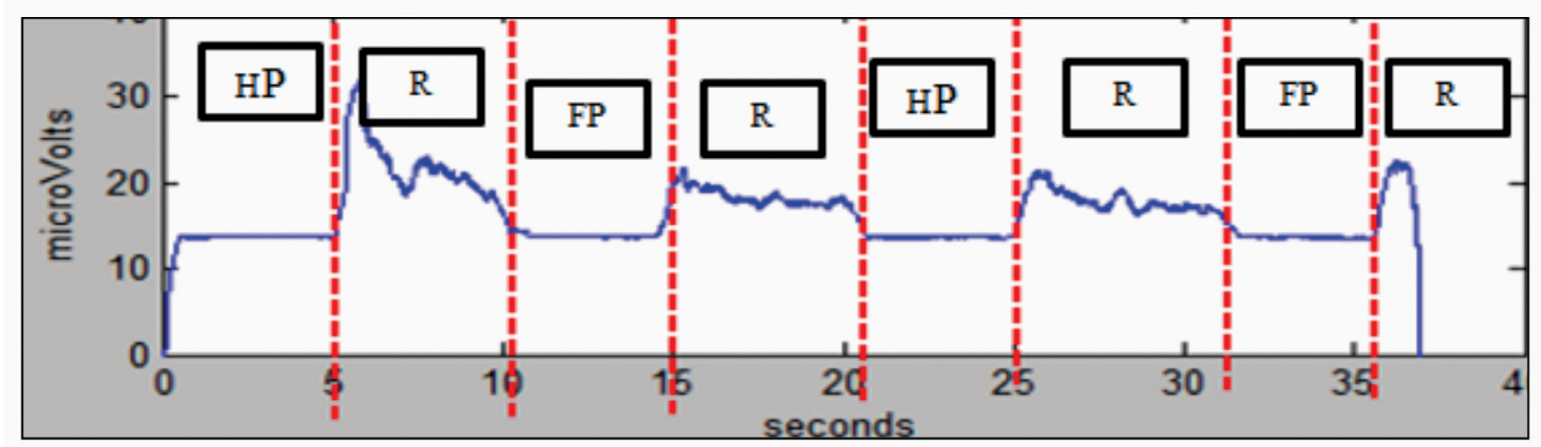

FIGURE 5. Temporal analysis of TA muscle according to pedal task

AMPLITUDE ANALYSIS

Figure 6 show the Amplitude Analysis for TA based on RMS value. As stated in the previous paragraph, the TA shows different pattern when pressing and releasing the pedal. In addition, there are some significant differences between each position. Further analysis using statistical analysis method is described after this section. The mean RMS value for $\mathrm{R}$ action is higher than the HP and FP actions. For HP action, the mean RMS values for pre-post activity for position A are $4.58(15 \%)$ and $5.18 \mu \mathrm{V}(15 \%)$ respectively. For R action, the mean RMS values is $10.09 \mu \mathrm{V}$ at \%MVIC $30 \%$. Meanwhile, for FP and HP action, the value is $6.37 \mu \mathrm{V}$ at $20 \%$ and 4.58 $\mu \mathrm{V}$ at $15 \%$, respectively.

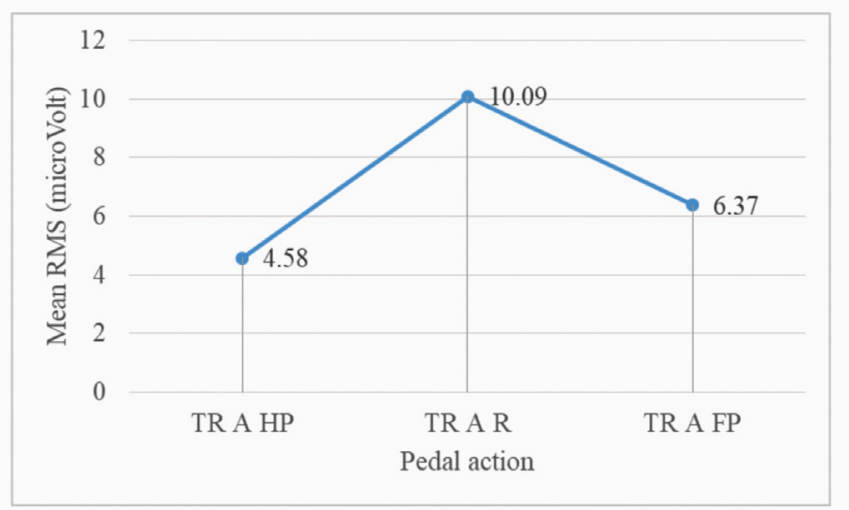

FIGURE 6. Amplitude analysis of TA muscle according to pedal task

\section{THOROUGH ANALYSIS ON ACCELERATOR PEDAL OPERATION}

A detailed analysis was carried out to identify the association between each variables using statistical analysis. In this section, the difference between action (HP, R and FP) is analysed using suitable statistical method. The Independence Variable is this case is one group that is measured on three different actions (HP, R and FP) and the Dependence Variable is the RMS value for three actions, HP, R and FP. There is significant difference between HP-R, FP-HP and R-FP after Wilcoxon signed-rank test was performed $(\mathrm{p}>0.05)$.

In this study, the TA is work in dorsiflexion position, which is referred to the releasing of the pedal. Dorsiflexion happens when the driver releases the pedal with the ankle joint angle is less than $90^{\circ}$ and at the maximum of $70^{\circ}$. Meanwhile, the plantar flexion occurs when the driver presses the pedal with the ankle joint angle greater than $90^{\circ}$. When releasing the car pedal, the TA showed the greatest muscle activation based on the RMS value, which is more than $5 \mu \mathrm{V}$. In contrast, when pressing the pedal, particularly at $\mathrm{HP}$ action, the TA showed the lowest activation which is less than $5 \mu \mathrm{V}$. According to these findings, it shows that the TA muscle is in the rest condition when half-pressing the pedal. According to Florimond (2009), the muscle is in the rest condition when its amplitude is between $+/-5 \mu \mathrm{V}$. If more than $+/-5 \mu \mathrm{V}$, it is then activated.

\section{CONCLUSION}

Leg placement while operating the car pedal is expected to engage with lower leg muscle activity. The finding from this study was supported with the principle of muscle loading to joint movement while coordinating the pedal. The primary muscle for pedal are numerous, however each muscle work differently based on the tasks. It consists of biomechanical movement in operating the pedal by applying different muscles and joint angle to control the pedal. In this study, the right $\mathrm{TA}$ is the prime mover when releasing the pedal (works in a dorsiflexion with ankle joint movement is less than 90 degrees).

In addition, different actions produce different muscle activation. In this study, pressing activity shows the lowest activation value compared to releasing action for TA muscle. Based on the study, TA muscle contracted below than $5 \mu \mathrm{V}$ for half pressing action. It shows that during half-pressing action, the TA muscle is in the rest condition. All in all, this study shows that the TA muscle works differently according to the car pedal actions. This action influence the driver's state when operating the car pedal.

\section{ACKNOWLEDGEMENT}

The authors would like to thank Universiti Kebangsaan Malaysia for their financial support under the grant GUP2017-094. 
REFERENCES

Adler, S. 2007. The relation between long-term seating comfort and driver movement. Dipl.-Sportwiss, Friedrich-Schiller-Universitat Jena.

Antonson, H., Ahlström, C., Mårdh, S., Blomqvist, G. \& Wiklund, M. 2014. Landscape heritage objects' effect on driving: a combined driving simulator and questionnaire study. Accident Analysis and Prevention 62: 168-177.

Auberlet, J.-M., Rosey, F., Anceaux, F., Aubin, S., Briand, P., Pacaux, M.-P. \& Plainchault, P. 2012. The impact of perceptual treatments on driver's behavior: from driving simulator studies to field tests--first results. Accident Analysis and Prevention 45: 91-98.

Bougard, C., Moussay, S. \& Davenne, D. 2008. An assessment of the relevance of laboratory and motorcycling tests for investigating time of day and sleep deprivation influences on motorcycling performance. Accident Analysis and Prevention 40(2): 635-643.

Costanzo, A., Graziani, G. \& Orsi, G. 1999. Driving ergonomy: New methodology for the assessment of stresses on upper limbs. Safety Science Monitor 3(2): $1-11$.

De Waard, D., Van den Bold, T.G. \& Lewis-Evans, B. 2010 Driver hand position on the steering wheel while merging into motorway traffic. Transportation Research Part F: Traffic Psychology and Behaviour 13(2): 129-140.

Döring, T., Kern, D., Marshall, P., Pfeiffer, M., Schöning, J., Gruhn, V. \& Schmidt, A. 2011. Gestural interaction on the steering wheel: reducing the visual demand. Proceedings of the 2011 Annual Conference on Human Factors in Computing Systems, 483-492.

Fatollahzadeh, K. 2006. A laboratory vehicle mock-up research work on truck driver's selected seat position and posture: A mathematical model approach with respect to anthropometry, body landmark locations and discomfort, Doctoral Thesis, Royal Institute of Technology.

Florimond, V. 2009. Basics of surface electromyography applied to Physical Rehabilitation and Biomechanics. Volume 1. Montreal, Canada: Thought Technology Ltd.

Fouladi, M. H., Inayatullah, O. \& Ariffin, A. K. 2011. Evaluation of seat vibration sources in driving condition using spectral analysis. Journal of Engineering Science and Technology 6(3): 339-356.

Gyi, D.E., Porter, J.M. \& Robertson, N.K. 1998. Seat pressure measurement technologies: considerations for their evaluation. Applied Ergonomics 29(2): 85-91.

Hirao, K., Kitazaki, S. \& Yamazaki, N. 2006. Development of new driving posture focused on biomechanical loads SAE International Journal 100: 5-10.

Kamp, I. 2012. The influence of car-seat design on its character experience. Applied Ergonomics 43(2): 329335.

Keene, D. 2010. Guide for assessing ankle range of movement for the AIM trial. Oxford, UK: Ankle Injury Management (AIM).
Kyung, G. 2008. An integrated human factors approach to design and evaluation of the driver workspace and interface: driver perception, behaviour, and objective measures. PhD Thesis, Virginia Polytechnic Institute and State University.

Maël, A., Etienne, P. \& Vincent, R. 2013. Multimodal approach to automobile driving comfort: The influence of visual setting on assessments of vibro-accoustic comfort in simulators. Applied Acoustics 74(12): 1378-1387.

Mansfield, N. J., Sammonds, G., Darwazeh, N., Massoud, S., Mocio, A., Patel, T. \& Sehdev, A. 2017. Movement analysis to indicate discomfort in vehicle seats.1st International Comfort Congress, Salerno, 7-8 June 2017.

Mossey, M. E., Xi, Y., McConomy, S.K., Brooks, J.O., Rosopa, P.J. \& Venhovens, P.J. 2014. Evaluation of four steering wheels to determine driver hand placement in a static environment. Applied Ergonomics 45(4): 1187 1195.

Porter, J.M. \& Gyi, D.E. 1995. Low back trouble and driving. Proceedings of the 2nd International Scientific Conference on Prevention of Work-related Musculoskeletal Disorders (PREMUS'95), Montreal, Canada, September 1995, 117-119.

Rudin-Brown, C. M., Edquist, J. \& Lenné, M. G. 2014. Effects of driving experience and sensation-seeking on drivers' adaptation to road environment complexity. Safety Science 62: 121-129.

Tanaka, Y., Kaneyuki, H., Tsuji, T., Miyazaki, T., Nishikawa, K. \& Nouzawa, T. 2009. Mechanical and perceptual analyses of human foot movements in pedal operation. Conference Proceedings - IEEE International Conference on Systems, Man and Cybernetics, 1674-1679.

Vilimek, M., Horak, Z. \& Petr, K. 2011. Optimization of shift lever position. Journal of Chemical Information and Modeling 53: 1689-1699.

Wang, X., Le Breton-Gadegbeku, B. \& Bouzon, L. 2004. Biomechanical evaluation of the comfort of automobile clutch pedal operation. International Journal of Industrial Ergonomics 34(3): 209-221.

Yusoff, A. R., Deros, B.M. \& Daruis, D.D.I. 2012. Vibration transmissibility on foot during controlling and Operating Car Accelerator Pedal. Proceedings of 4th International Conference on Noise, Vibration and Comfort (NVC 2012), 27-28 November 2012, Kuala Lumpur, Malaysia, 210-215.

*Nor Kamaliana Khamis

Programme for Mechanical Engineering,

Centre for Engineering Materials and Smart Manufacturing (MERCU),

Faculty of Engineering \& Built Environment, Universiti Kebangsaan Malaysia, Bangi, Malaysia. 
Baba Md Deros, Mohd Zaki Nuawi

Programme for Mechanical Engineering,

Centre for Integrated Design of Advanced Mechanical System (PRISMA),

Faculty of Engineering \& Built Environment, Universiti Kebangsaan Malaysia, Bangi, Malaysia.

Dieter Schramm

Department of Mechanical and Process Engineering,

Faculty of Engineering,

University of Duisburg-Essen, Germany.

*Corresponding author; email: kamaliana@ukm.edu.my

Received date $: 19^{\text {th }}$ September 2017

Accepted date : $30^{\text {th }}$ January 2018

In Press date : $1^{\text {st }}$ April 2018

Published date : $30^{\text {th }}$ April 2018 